\title{
Business Diplomacy Strategies and Instruments: Biotechnology Companies Promoting g Mos in Mexico
}

\author{
Yadira Ixchel Martínez Pantoja
}

Dept. of Politics and International Relations, The University of Auckland, Auckland 1142, New Zealand

ymar183@aucklanduni.ac.nz

Received: 1 February 2018; revised: 23 July 2018; accepted: 5 September 2018

\section{Summary}

Business diplomacy emphasizes engagement with stakeholders to shape the environment to favour business interests. This article recognizes that multinational corporations (MNCs) play a relevant role in the international arena, dealing with governments and other non-state actors by means of business diplomacy. Biotechnology companies, in particular, bargain with government representatives for commercialization, deregulation or intellectual property enforcement. In order to advance their economic and business goals, biotechnology companies have implemented reactive, proactive and relationship-building strategies and instruments. These MNCs have applied reactive instruments to respond to evolving problems and proactive instruments to address more complex issues. MNCs have also employed long-term relationship-building instruments, such as awards and research centres, to establish stronger relationships with multiple stakeholders. This article contributes to the discussion of what business diplomacy is and presents an analysis of strategies and instruments that is scarce in the business diplomacy literature.

\section{Keywords}

business diplomacy - diplomacy strategies - relationship building - genetically modified (GM) foods - biotechnology - multinational corporations (MNCs) - Mexico 


\section{Introduction}

A worldwide debate exists about genetically-modified (GM) foods, with two contrasting positions. Proponents of GM foods - including biotechnology companies, industry associations and some non-governmental organizations (NGOs) - emphasize the benefits of GM food for agriculture, sustainability and alleviating world hunger. In contrast, opponents - predominantly environmental NGOs - highlight the risks of GM food for the environment, human health and food sovereignty. These polarized positions, mixed messages and distorted arguments have contributed to consumer scepticism and charged public emotions. In the United States, GM foods have been consumed for over a decade. However, since the 1970s, when biotechnology offered its first developments, opponents have highlighted links with socio-political issues including environmental protection, the future of technology and manipulation of the building blocks of life, thus raising moral concerns. ${ }^{1}$ These differences in positions have been intensified by the influence of non-state actors, such as environmental NGOS, private interest groups and the public, with all these actors shaping the global debate. ${ }^{2}$ Therefore, the complexity of the GM food debate results from different influential forces in society, including economics, government, regulation, mass media, politics and religion. ${ }^{3}$

Mexico is in the midst of the GM food debate. Corn is a central part of Mexico's national identity and its main food staple. The cultivation of GM seeds - which imply monocrops, pesticides and patents - may threaten multiple maize varieties and Mexico's biodiversity. Much of Mexico's agrarian system, especially small-scale farmers, is unprepared for this production model, and ancestral practices linked to maize may be disrupted by the introduction of genetically modified organisms $(\mathrm{GMOs})^{4}$ in the cornfields. Regardless, Mexico imports 20 million tons of corn a year from the United States, which mainly produces GM corn. Biotechnology companies producing these seeds are interested in selling their technological packages in Mexico

1 Petra Grabner, Jürgen Hampel, Nicola Lindsey and Helge Torgersen, 'Biopolitical Diversity: The Challenge of Multilevel Policy-Making', in George Gaskell and Martin W. Bauer (eds), Biotechnology, 1996-20oo: The Years of Controversy (London: Science Museum, 2001), p. 16.

2 Robert Falkner, 'Global Biotech Food Fight: Why the United States Got It So Wrong', Brown Journal of World Affairs vol. XIV, no. 1 (2008), p. 100.

3 Martin W. Bauer and George Gaskell, 'Researching the Public Sphere of Biotechnology', in Martin W. Bauer and George Gaskell (eds), Biotechnology: The Making of a Global Controversy (Cambridge: Cambridge University Press, 2002), p. 1.

4 The term gmo includes plants, animals, bacteria, virus, seeds, crops and transgenic foods or genetically modified foods. In this article, the term GM foods will be used to refer to genetically modified crops, seeds, foods, feed and derived food products. 
because it represents an important market. Consequently, these multinational corporations (MNCs), sometimes with the support of the US government, actively promote GMOs in Mexico to change their image and shape the political environment.

MNCs nowadays play a significant role as enhancers of governmental public diplomacy activities and have become important allies of states in the international arena when pursuing similar goals. Not only governments work to open and encourage markets for business; companies also make efforts to shape and change the international political environment and favour their investments in different markets. The relationship between companies and governments has changed, inasmuch as they have become closer and more like each other. ${ }^{5}$ MNCs employ new ways to interact with governments beyond lobbying and public relations to promote favourable environments in overseas countries, participating in some public diplomacy programmes and utilizing business diplomacy as part of their corporate strategy. This article focuses on how biotechnology companies implement business diplomacy strategies and instruments to promote GMOs in Mexico.

\section{Business Diplomacy Embedded in Public Diplomacy}

Thanks to globalization, states compete in opening more markets to their companies' products and services, attracting foreign investment, and persuading MNCs to stay in the country and not relocate offshore. This dynamic produces the negotiation of partnerships between the government of a host country and MNCs, in which both aim to grow world market shares. ${ }^{6}$ MNCs participate with governments in public-private partnerships to advance common goals as part of public diplomacy. ${ }^{7}$ The efforts performed by state and non-state actors to manage and change the international environment through engaging with publics in a host country are called public diplomacy. ${ }^{8}$ Moreover, non-state

5 Wally Olins, Trading Identities: Why Countries and Companies Are Taking on Each Others' Roles (London: Foreign Policy Centre, 1999), p. 1.

6 Susan Strange, 'Rethinking Structural Change in the International Political Economy: States, Firms, and Diplomacy', in Richard Stubbs and Geoffrey R.D. Underhill (eds), Political Economy and the Changing Global Order (London: Macmillan, 1994), p. 107.

7 Yadira I. Martínez Pantoja, 'Conceptualizing a New Public Diplomacy Model: "Intermestic" Strategies and Instruments to Promote Change in Mexico's GM Food Policy', The Hague Journal of Diplomacy vol. 13, no. 3 (2018), pp. 245-271 .

8 Nicholas J. Cull, 'Public Diplomacy: Lessons From the Past', CPD Perspectives on Public Diplomacy (Los Angeles, CA.: Figueroa Press, 2009), p. 12. 
actors such as MNCs develop strategies for communication and influence, as well as dialogue engagement techniques as a part of public diplomacy. ${ }^{9}$ To MNCs, the use of public diplomacy is vital for creating a favourable policy environment to expand their markets and disseminate messages to persuade stakeholders.

MNCs are not only interested in selling products and being in the minds and hearts of their consumers; they also want to gain support from the host governments where they operate. An inherent characteristic of public diplomacy is that MNCs cooperate with governments to influence policy. ${ }^{10}$ Public diplomacy works well to engage different stakeholders, manage reputation and build confidence with non-elite stakeholders. ${ }^{11}$ For instance, to have more effective US public diplomacy activities, American companies play a key role as influencers, because their brands and representatives may have more direct contact with people in the host country than government representatives. ${ }^{12}$ MNC participation in public diplomacy thus becomes vital to reinforce governmental activities promoting a positive political environment in a host country. MNCs' participation in public diplomacy may be used to convey tactical messages and be part of the country's legitimacy strategy in the host country, because business diplomacy is more than just MNC participation in public diplomacy programmes supported by governments; it implies firms developing and implementing their own programmes and capabilities to pursue similar diplomatic goals as state actors. ${ }^{13}$

According to Huub Ruël, business diplomacy refers to 'the representation and communication activities deployed by international businesses with host government representatives and non-governmental representatives in order to establish and sustain a positive relationship to maintain legitimacy and a license to operate.14 Moreover, business diplomacy has three main focuses:

9 Teresa La Porte, "The Impact of "Intermestic" Non-State Actors on the Conceptual Framework of Public Diplomacy', The Hague Journal of Diplomacy, vol. 7 (2012), p. 446.

10 Brian Hocking, 'Rethinking the "New" Public Diplomacy', in Jan Melissen (ed.), The New Public Diplomacy: Soft Power in International Relations (Basingstoke: Palgrave Macmillan, 2005), p. 38.

11 George Haynal, 'Corporate Statecraft and Its Diplomacy', The Hague Journal of Diplomacy, vol. 9, no. 4 (2014), p. 413.

12 Joseph S. Nye, 'Public Diplomacy and Soft Power', The ANNALS of the American Academy of Political and Social Science 616 (March 2008), p. 105.

13 Enric Ordeix-Rigo and João Duarte, 'From Public Diplomacy to Corporate Diplomacy: Increasing Corporation's Legitimacy and Influence', American Behavioral Scientist, vol. 53, no. 4 (2009), p. 555.

14 Huub Ruël, 'Diplomacy Means Business', Windersheimreeks Kennis en Onderzoek 46 (Zwolle: Windesheim, 2013), p. 41. 
foreign state and non-state actors; establishment of long-term relationships; and legitimacy creation in a host country. ${ }^{15}$ These three main focuses are critical to create a positive environment for businesses. Business diplomacy also involves making the environment suitable for companies to operate and reducing possible risks and uncertainty. ${ }^{16}$ To achieve this favourable environment and seize business opportunities, business diplomacy involves persuading and influencing social and economic actors in national and international bodies, anticipating possible conflicts with stakeholders, and utilizing different media channels and forums to preserve a company's reputation and image. ${ }^{17}$

Additionally, business diplomacy involves engagement with diverse stakeholders to sell a firm's services, boost reputation and find common ground for possible alliances. ${ }^{18}$ Consequently, MNCs deal with different stakeholders that may affect their performance, including international organizations, governmental agencies and NGOs. To be successful in influencing people, companies need to win public trust and persuade stakeholders that they are sincere..$^{19}$ Managing multiple domestic and international stakeholders is vital for business to succeed and ensure sustainable economic viability and investment. ${ }^{20}$ This article argues that business diplomacy is a subset of public diplomacy, and that when MNCs move from common goals with governments to manage stakeholders independently to achieve higher reputation, a favourable political environment, stakeholder alliances and ultimately profitability goals, they are performing business diplomacy. Moreover, business diplomacy highlights the commitment of MNCs to establish long-term relationships with

15 Huub Ruël and Tim Wolters, 'Business Diplomacy', in Costas M. Constatinou, Pauline Kerr and Paul Sharp (eds), The SAGE Handbook of Diplomacy (Thousand Oaks, CA: SAGE, 2016), p. 569 .

16 Raymond Saner, 'Effective Business Diplomacy', Extraordinary and Plenipotentiary Diplomatist (2016), p. 17, available online at http://diplomatist.com/annualedition.html.

17 Raymond Saner, Lichia Yiu and Mikael Sondergaard, 'Business Diplomacy Management: A Core Competency for Global Companies', Academy of Management Executive, vol. 14, no. 1 (2000), p. 85 .

18 Raymond Saner and Lichia Yiu, 'Business Diplomacy Competence: A Requirement for Implementing the OECD's Guidelines for Multinational Enterprises', The Hague Journal of Diplomacy, vol. 9, no. 4 (2014), p. 321.

19 Olins, Trading Identities, p. 38.

20 Raymond Saner and Lichia Yiu, 'Swiss Executives as Business Diplomats in the New Europe: Evidence from Swiss Pharmaceutical and Agro-Industrial Global Companies', Organizational Dynamics, vol. 34, no. 3 (2005), p. 301. 
diverse stakeholders. ${ }^{21}$ The main actors in business diplomacy are the companies and their employees, who seek to secure the company's profitability and permanence. $^{22}$

Business diplomacy operates with a range of activities, mainly participating in cross-sectorial interaction with international and local NGOs and civil society organizations; taking part in negotiations along with state actors to secure favourable deals; and influencing organizations to secure the inclusion of MNCs. ${ }^{23}$ Some business diplomacy activities rely on a state's diplomatic resources and relationship to advance the converged interests of the government and the MNC. ${ }^{24}$ Hence, business diplomacy is embedded in public diplomacy because state actors also interact with stakeholders and contribute to shaping the political environment of a host country. Business diplomacy capabilities include identifying governmental and non-governmental actors that may pose a risk to the business environment, developing coalitions between stakeholders, and building multi-level networks of information and influence. ${ }^{25}$ For example, biotechnology companies have employed structural, instrumental and discursive power to alter forums, and have joined states to change rules, specifically related to intellectual property rights, into trade discussions such as the US Trade Representative, the General Agreement on Tariffs and Trade, and the World Trade Organization (wTO). ${ }^{26}$ This strategy of negotiating and interacting at different levels gives MNCs presence, power and influence, and shows the intertwined nature of public diplomacy and business diplomacy.

21 Huub Ruël and Luisa Suren, 'Introduction to the Volume International Business Diplomacy: A Strategy for Improving MNCs' Performance? A Review of the Concept and New Insights from Five European MNCs', in Miguel R. Olivas-Lujan, Tanya Bondarouk and Huub Ruël (eds), International Business Diplomacy: How Can Multinational Corporations Deal with Global Challenges? (Bingley: Emerald Publishing Limited, 2017), p. 4.

22 Jennifer Kesteleyn, Shaun Riordan and Huub Ruël, 'Introduction: Business Diplomacy', The Hague Journal of Diplomacy, vol. 9, no. 4 (2014), p. 304.

23 Saner and Yiu, 'Business Diplomacy Competence', pp. 317-318.

24 James M. Small, 'Business Diplomacy in Practice: Advancing Interests in Crisis Situations', The Hague Journal of Diplomacy, vol. 9, no. 4 (2014), p. 377.

25 Shaun Riordan, 'Business Diplomacy: Shaping the Firm's Geopolitical Risk Environment', Policy Brief (The Hague: Clingendael Institute, 2014), pp. 1 and 2, available online at https:// www.clingendael.org/sites/default/files/pdfs/Shaun\%2oRiordan\%20-\%2oBusiness \%20Diplomacy\%20-\%20October\%202014.pdf.

26 Susan K. Sell, 'Corporations, Seeds, and Intellectual Property Rights Governance', in Jennifer Clapp and Doris Fuchs (eds), Corporate Power in Global Agrifood Governance (Cambridge, MA: MIT Press, 2009), p. 188. 


\section{Biotechnology Companies as a Case Study}

According to Eytan Gilboa, in order to study public diplomacy, case studies may be categorized based on actors, instruments and geographical areas. ${ }^{27}$ The study of biotechnology companies as a case study derives from my doctoral research in which I analysed three actors involved in public diplomacy: state actors; MNCs; and NGOS. Empirical evidence for this article stems from my doctoral field research conducted from December 2013 to February 2014 in Mexico City, and July 2015 in Washington DC. Using a qualitative approach, I conducted in-depth interviews with government officials, diplomats and NGO directors, and undertook documentary analysis, examining academic sources, official statements, websites and documents, biotechnology companies' and NGOs' brochures, press releases, media articles, media interviews with CEOs and directors, and internal documents. I performed thematic analysis to examine the most relevant messages delivered by biotechnology companies and environmental groups, and to identify explicit and implicit appeals. For this article, I focused on the strategies and instruments of business diplomacy used only by biotechnology companies involved in the promotion of GMOs in Mexico, not the biotechnology sector in general.

This research is relevant to explain the ways in which biotechnology companies have used business diplomacy strategies and instruments to promote their interests and create a favourable environment in Mexico. There are different studies about business diplomacy theory and its applications, but little research has been undertaken to identify the specific strategies and instruments that MNCs utilize. Scholarly research of business diplomacy has been scarce and limited to the analysis of operations and tools in Europe. ${ }^{28}$ This article therefore contributes to the study of theory and practice of business diplomacy in an emerging market such as Mexico. Moreover, the article itemizes biotechnology companies' strategies and instruments to oppose criticism of their GMO products, which have been useful in countering civil-society organizations and policy-makers' resistance in Mexico.

Biotechnology companies are at the centre of bargaining with policy-makers over regulations related to development and distribution of GM foods because they have some global control over supply chains. ${ }^{29}$ For example, Monsanto

27 Eytan Gilboa, 'Searching for a Theory of Public Diplomacy', The ANNALS of the American Academy of Political and Social Science, vol. 616 (March 2008), pp. 55-77.

28 Ruël, 'Diplomacy Means Business', pp. 41 and 42.

29 Peter Newell, 'Globalization and the Governance of Biotechnology', Global Environmental Politics, vol. 3, no. 2 (2003), p. 68. 
and other biotechnology companies have a confident position in the US market because the US government gives priority to business, government agencies provide institutional and political support, and the mass public lacks interest in it. ${ }^{30}$ The combination of all these factors has allowed biotechnology companies to interact with governments in negotiations and to deliver useful information for future regulations. Moreover, biotechnology companies have received support from the government to research and develop GM crops, including subsidies, supportive infrastructure, less-restrictive policy frameworks, public-private partnerships, ${ }^{31}$ tax incentives, soft loans and duty-free imports of sophisticated equipment. ${ }^{32}$ These incentives have promoted research and development of new GM products and have helped companies to reach their profitability goals.

The predominant biotechnology companies in the agricultural sector are the result of strategic mergers and acquisitions, including Monsanto, DowChemical with its sub-group Dow AgroSciences, DuPont with DuPont Pioneer, Bayer with Bayer CropScience, Syngenta and BASF. This 'big six' collectively hold a unique position in the market and integrate biological and chemical technologies in agricultural markets. ${ }^{33}$ These MNCs controlled 76 per cent of global agrochemical sales, 75 per cent of private-sector plant-breeding research, and 60 per cent of the commercial seed market in 2011. ${ }^{34}$ In 2017, DowChemical and DuPont merged, ChemChina acquired Syngenta, and Bayer completed a merger with Monsanto in 2018, thus reducing this business sector to four major participants and further concentrating their power. This article will refer to these companies as biotechnology companies.

30 David L. Levy and Peter Newell, 'Oceans Apart? Business Responses to Global Environmental Issues in Europe and the United States', Environment: Science and Policy for Sustainable Development, vol. 42, no. 9 (2000), p. 13.

31 Dominic Glover and Peter Newell, 'Business and Biotechnology: Regulation of GM Crops and the Politics of Influence', in Kees Jansen and Sietze Vellema (eds), Agribusiness \& Society: Corporate Responses to Environmentalism, Market Opportunities and Public Regulation (London: Zed Books, 2004), p. 207.

32 Newell, 'Globalization and the Governance of Biotechnology', p. 62.

33 Keith O. Fuglie et al., Research Investments and Market Structure in the Food Processing, Agricultural Input, and Biofuel Industries Worldwide (Washington, DC: USDA Economic Research Service, 2011), p. 30.

34 Eтc Group, 'Putting the Cartel before the Horse ... and Farm, Seeds, Soil, Peasants, Etc.' (2013), p. 3, available online at http://www.etcgroup.org/content/new-report-puttingcartel-horse....and-farmseeds-soil-peasants\#_edn. 
These MNCs also manufacture chemical products and have already established strong relationships with regulators at different levels of jurisdiction. ${ }^{35}$ Commercializing chemicals gives these companies further experience, liaisons and opportunities to interact with different regulators, as well as expertise about how to nurture long-term relationships. Biotechnology companies have influenced the US government because of their increasing importance to the economy, combined with the desire of different administrations to support the biotechnology industry's rise and maintain the United States' position as a global leader in agriculture. ${ }^{36}$ Moreover, biotechnology companies promote a shared understanding of agricultural biotechnology, are aware of public resistance to biotechnology products, have preferences for certain regulatory instruments and operate together to secure non-restrictive GM foodgoverning arrangements. ${ }^{37}$ In particular, biotechnology companies seek GMO deregulation from overseas governments and global enforcement of intellectual property rights, GM technologies, patented organisms and agrochemicals because these policies facilitate the expansion of their worldwide markets. ${ }^{38}$ Progress in negotiations with overseas governments, deregulation, intellectual property enforcement and business success has been achieved in part by business diplomacy.

Although biotechnology companies have passed approval processes in Mexico because the 2005 Law on Biosafety of Genetically Modified Organisms allows commercial planting of GM crops, their GM soy and GM maize permits have been suspended as a result of NGO activism to protect maize, indigenous people and food sovereignty. GM foods in Mexico are an 'intermestic' (that is, both international and domestic) issue where state and non-state actors have participated in public diplomacy activities to shape policy on GM foods. ${ }^{39}$ Business diplomacy focuses on strategic coalitions between state and nonstate actors in order to shape the environment in which a company faces risks. ${ }^{40}$ Furthermore, the identification of both geopolitical and non-commercial risks and international actors who mediate those risks, such as state and non-state

35 Peter Newell and Dominic Glover, 'Business and Biotechnology: Regulation and the Politics of Influence', IDS Working Paper no. 192 (Brighton: Institute of Development Studies, 2003), p. 4.

36 Levy and Newell, 'Oceans Apart?', p. 13.

37 Marc Williams, 'Feeding the World? Transnational Corporations and the Promotion of Genetically Modified Food', in Jennifer Clapp and Doris Fuchs (eds), Corporate Power in Global Agrifood Governance (Cambridge, MA: MIT Press, 2009), p. 166.

38 Kathleen McAfee, 'Beyond Techno-Science: Transgenic Maize in the Fight over Mexico's Future', Geoforum, vol. 39, no. 1 (2008) p. 151.

39 Martínez Pantoja, 'Conceptualizing a New Public Diplomacy Model'.

40 Riordan, 'Business Diplomacy', p. 1. 
actors, is essential for business diplomacy to operate ${ }^{41}$ Consequently, analysing the business diplomacy strategies and instruments of biotechnology companies is essential for understanding how they operate to secure a complex but promising market such as Mexico.

\section{Strategies, Instruments and Activities}

Business diplomacy occurs when the economic interests of a company align with the home country's national interests to overcome hostile actions or barriers posed by a host government to the company. ${ }^{42}$ Business diplomacy is not necessarily about a company's image or reputation, unless that it is central to managing any geopolitical risk, because the main purpose of business diplomacy is to assist a company to make profits at an international level. ${ }^{43}$ Moreover, business diplomacy is more centred in building and maintaining relationships with government representatives and non-state stakeholders of a host country. ${ }^{44}$ Although the emphasis of business diplomacy is on long-term relationship management, this article argues that MNCs also employ other strategies and instruments to engage with different stakeholders, gain legitimacy and operate, utilizing reactive and proactive communication strategies to respond to eventualities and engage in short- to medium-term activities with non-state actors.

With regard to Mexico's policy environment, biotechnology companies may face an emerging market with some risks. Business diplomacy therefore becomes indispensable for securing profits and changing the reputation of biotechnology companies among Mexican stakeholders. Considering the model of public diplomacy that I developed involving reactive, proactive and relationship-building strategies and instruments such as press releases, audiovisual productions, conferences, awards and exhibits, ${ }^{45}$ this article proposes a similarly comprehensive approach for business diplomacy strategies and instruments that biotechnology companies utilize to promote GM foods in Mexico, not only limited to long-term relationships, but also with reactive and proactive dimensions.

\footnotetext{
41 Kesteleyn, Riordan and Ruël, 'Introduction: Business Diplomacy', p. 306.

42 Small, 'Business Diplomacy in Practice', p. 377.

43 Kesteleyn, Riordan and Ruël, 'Introduction: Business Diplomacy', p. 306.

44 Ruël, 'Diplomacy Means Business', pp. 14-15.

45 Martínez Pantoja, 'Conceptualizing a New Public Diplomacy Model'.
} 
Reactive and proactive communication strategies help MNCs to persuade stakeholders with diverse messages and thus shape opinions about current or controversial issues, or to respond to potential crises that companies may face. Some of the instruments that business diplomacy may employ include lobbying governmental and non-governmental stakeholders, plus corporate socialresponsibility programmes. ${ }^{46}$ Many public relations instruments have been adopted in the public diplomacy area because the conduct of public diplomacy communications with different audiences operates similarly to public relations. ${ }^{47}$ Furthermore, business diplomacy's main functions are conducted by the CEO or CEO's office and can also be taken up by staff functions, including public relations, which can be decentralized at the CEO's consideration. ${ }^{48}$ Public relations instruments are hence essential for business diplomacy when framed in a political context where companies can be hindered in a goal, market or permit. However, while some of the instruments that this article analyses may appear to be public relations tactics, when MNCs employ them to change the political and economic environments to advance their agenda, build relationships and gain legitimacy, these work as business diplomacy instruments.

\section{Reactive Strategic Communication}

Reactive strategic communication includes media releases and press conferences to react to an evolving problem. In the 199os, public affairs was limited to background operations to promote and protect a company's reputation and position in the global arena, making sure that the CEO appeared fine and the company stayed away from unfavourable press releases..$^{49}$ Monsanto and other agrochemical companies that have had troubles with values and public trust, and a shallow style of public relations, have gained the title of villains in the GMO debate because the mass public has been sceptical about their standards and behaviour. ${ }^{50}$ Monsanto has used press releases to respond to accusations about being an untrustworthy firm because it developed Agent Orange, which was used in the Vietnam War, and now sells pesticides. ${ }^{51}$ Monsanto also has

46 Kesteleyn, Riordan and Ruël, 'Introduction: Business Diplomacy', p. 304.

47 Jan Melissen, The New Public Diplomacy: Soft Power in International Relations (Basingstoke: Palgrave Macmillan, 2005), p. 21.

48 Saner and Yiu, 'Business Diplomacy Competence', p. 318.

49 James P. Muldoon, 'The Diplomacy of Business', Diplomacy \& Statecraft, vol. 16, no. 2 (2005), p. 355 .

5o Olins, Trading Identities, pp. 38-39.

51 Monsanto, 'Agent Orange: Background on Monsanto's Involvement', Monsanto Newsroom, available online at http://www.monsanto.com/newsviews/pages/agent-orange-back ground-monsanto-involvement.aspx (accessed 1o February 2015). 
used media releases to project a favourable image thorough its website, with a section of viewpoints covering the company's main achievements. For example, the news release 'UsDA Deregulates Monsanto's Next-Generation Weed Control Trait Technology' emphasizes the company's products that have been deregulated and are available for farmers. ${ }^{52}$ These news releases are a key way to communicate the company's achievements as well as new product research and development to bring more solutions to farmers. They also help the company to project a good image and commitment to transparency.

In another example, when Bayer's General Director Kurt Soland was appointed to his position in 2010, the newspapers El Universal and Excelsior ${ }^{53}$ interviewed him. Soland mentioned the company's objectives and how Bayer can contribute to Mexico's economic development and enhance the agrarian sector's productivity, announcing the launch of ten new products for 2012. ${ }^{54}$ These media releases assisted Bayer in building an image of commitment to Mexico's needs with a sense of social responsibility, portraying a company concerned about social problems, creating a connection with the media and engaging the public and stakeholders. Media releases are a valuable instrument for sharing reports or strategic information as a tactic to show corporate social responsibility. ${ }^{55}$ Furthermore, corporate social responsibility can be considered an important element in the implementation of business diplomacy to influence policy-makers in the host country and to benefit companies. ${ }^{56}$

\section{Proactive Strategic Communication}

Proactive strategies involve more elaborate instruments and activities that include detailed information and specific targets to promote an issue. MNCs try to influence the public's point of view in various ways, such as with educational material. ${ }^{57}$ Generating such material containing technical language is an instrument that helps companies to change public opinion about their products,

52 Monsanto, 'USDA Deregulates Monsanto's Next-Generation Weed Control Trait Technology', Monsanto Newsroom, available online at http://news.monsanto.com/pressrelease/usda-deregulates-monsantos-next-generation-weed-control-trait-technology (accessed 10 February 2015).

53 Two national newspapers with high circulation in Mexico.

54 Héctor Rendón, 'Depender de EU nos limita', Excelsior (2010), available online at http:// www.bayercropscience.com.mx/bayer/cropscience/bcsmexico.nsf/id/oC4DEC4EFEC 7 Bo E7C1257736oo4AF131/\$file/entrevistaexcelsior.pdf.

55 Muldoon, 'The Diplomacy of Business', p. 351.

56 Ruël and Wolters, 'Business Diplomacy', p. 568.

57 Ian H. Rowlands, 'Transnational Corporations and Global Environmental Politics', in Daphné Josselin and William Wallace (eds), Non-State Actors in World Politics (Basingstoke: Palgrave Macmillan, 2001), p. 143 . 
in this case GM foods. The material includes audio-visual productions with the following advantages: unlimited reviews; appealing images to convey a stronger message; and easy dissemination through different communication media.

Biotechnology companies generate audio-visual productions to promote not only the benefits of GM foods but also the company's products, research, development, specific vocabulary and contribution to society. For example, DuPont has a channel on YouTube to show audio-visual materials about the company's developments and contributions to the world. ${ }^{58}$ In these videos, top executives present DuPont's official position about different themes. For instance, DuPont's Crop Protection President Rik Miller discusses the role of science and the importance of crop protection in contributing to food security. ${ }^{59}$ DuPont Mexico's channel presents the same material with subtitles in Spanish, but it is relevant because Executive Vice-President Jim Borel explains the way in which DuPont works closely with farmers to fight malnutrition by using improved seeds, ${ }^{60}$ which could be applied to Mexican farmers. The presence of top executives in audio-visual productions gives the idea that they care about farmers' problems and provides the company with an appearance of social responsibility by contributing to economic prosperity. Audiovisual productions give viewers time to digest the information, learn the technical language and engage external stakeholders with MNCs.

Bayer CropScience also produces audio-visual material presented on its YouTube channel, with videos about agriculture and public health, innovative solutions to increase yields, real experiences with farmers, and the inauguration of their research and development centres. ${ }^{61}$ Bayer's audio-visuals target farmers and the general public, such as a video presenting questions and answers about what Bayer CropScience does. ${ }^{62}$ This production allows the company to present technical language as well as the benefits of using its technology to solve social problems.

Syngenta's YouTube channel presents three distinct categories for its audiovisual materials: the Good Growth Plan; interviews with executives; and case studies. Various videos emphasize the company's Good Growth Plan campaign, which promotes Syngenta's contribution to solving the problem of feeding the world over the next 50 years. ${ }^{63}$ There is an interview with Syngenta's CEO Mike Mack, who presents the 2014 financial results in different parts of the world,

\footnotetext{
$5^{8}$ See https://www.youtube.com/user/DuPont/featured.

59 See http://youtu.be/AC-pOVIdeLs.

6o See http://youtu.be/JBnqd3PHZ8c.

61 See https://www.youtube.com/user/BayerCropScienceUS.

62 See http://youtu.be/agy3FJ5LBgg?list=PL7649122CF706ED46.

63 See http://youtu.be/tqIikYNo27U.
} 
business highlights and innovation results. ${ }^{64} \mathrm{~A}$ CEO's role in business diplomacy is as a definitive interlocutor between the company and the external world, similar to the role of heads of government who conduct personal diplomacy to represent a complete structure. ${ }^{65}$ Hence, the presentation of the CEO in audiovisual materials projects a sense of trust and transparency for the company.

Dow AgroSciences' YouTube channel introduces audio-visual materials from the company around the world, explaining how its products may solve farmers' problems. ${ }^{66}$ It also includes videos about how its products work in the field. Although these company videos do not include interviews with executives, they incorporate interviews with general managers conducted on television. They also include some testimonials from farmers affirming the success that they have had by using Dow AgroSciences' products. ${ }^{67}$ These audio-visual productions aid the company to promote its products and project a sense of social responsibility by presenting solutions.

On its YouTube channel, BASFAgro displays a series of audio-visual productions related to enhancing farmers' work in the world, labelling farming as the 'biggest job'.68 Additionally, there are other videos related to the events that BASFAgro has organized and a playlist devoted to the topic of sustainability, explaining how BASF Crop Protection contributes to worldwide sustainability. These videos allow BASF to promote its products and technological solutions. Furthermore, its emphasis on recognizing the farmer's labour appeals directly to farmers, because they may perceive the company as sympathetic to their job and the videos show the importance that farmers represent to the company and society.

In these audio-visual materials, biotechnology companies emphasize how they contribute to solving the world's farming problems, how producers will face higher demands for food in the future, and, therefore, the companies' possible solutions to alleviate global hunger. As a result, audio-visual productions are a useful instrument among companies and stakeholders familiar with technology. This instrument also helps to deliver information to government officials, because this is public material, easy to access, and with appealing images and content. It is an outstanding way to train in scientific language and an excellent instrument to show how the company responds to social or environmental problems.

64 See http://youtu.be/4LtvuBqi47U.

65 Haynal, 'Corporate Statecraft and Its Diplomacy', p. 412.

66 See https://www.youtube.com/user/DowAgroSciences.

67 See http://youtu.be/RN34rvg_wNE.

68 See https://www.youtube.com/user/BASFAgro/featured. 


\section{Relationship-building Strategic Communication}

Business diplomacy uses techniques from traditional diplomacy and instruments of public diplomacy to cultivate networks of information and influence. ${ }^{69}$ Business diplomacy not only deals with advancing short-term business agendas in the corridors of state power, but also deals with aligning the company's long-term interests with the 'license-issuing powers' that may affect the company. ${ }^{70}$ In order to establish stronger links with stakeholders, MNCs may employ long-term relationship-building strategies. By influencing perceptions and convincing policy-makers on the MNCs' arguments, the political environment can be changed, and regulations may favour companies. Innovative public diplomacy strategies in business diplomacy go beyond lobbying and marketing to engaging with civil societies. ${ }^{71}$ Long-term relationshipbuilding strategies also include instruments such as awards and scientific centres that contribute to the creation of networks and lasting relationships, as analysed below.

\section{Lobbying Networks}

From a business-diplomacy perspective, the main objective of lobbying is to secure the company's license to operate' from governments and make this permit the least costly and most competitive deal. ${ }^{72}$ Lobbying can be performed by biotechnology companies' representatives or through industry groups to have a stake in government and influence policy-makers on certain regulations. This powerful tactic has been implemented domestically and internationally because of the MNCs' interests overseas and to build networks. Lobbying a home government has the advantages of accessing policy-makers in regular private meetings, conversations at clubs, or through personal contacts, so that policymakers may sometimes satisfy MNCs' petitions. ${ }^{73}$ For example, to prevent GMO labelling, the US farm lobby and industry groups have been the most vocal supporters of GM foods. ${ }^{74}$ Biotechnology companies themselves have also lobbied to prevent such legislation.

\footnotetext{
69 Riordan, 'Business Diplomacy', p. 4.

70 Haynal, 'Corporate Statecraft and Its Diplomacy', p. 411.

71 Riordan, 'Business Diplomacy', p. 6.

72 Haynal, 'Corporate Statecraft and its Diplomacy', p. 411.

73 Rowlands, 'Transnational Corporations and Global Environmental Politics', p. 138.

74 Heike Baumüller, 'Trade in Biotechnology: Development and the Clash of Collective Preferences', in Ricardo Meléndez-Ortiz and Vicente Sánchez (eds), Trading in Genes: Development Perspectives on Biotechnology, Trade and Sustainability (Sterling, VA: Earthscan, 2005), p. 61.
} 
Monsanto has lobbied to maintain the current US regulatory system and to prevent GMOs from being treated differently from conventional counterparts, allocating US\$ 18.5 million from 1999 to 2004, in preserving the principle of substantial equivalence. ${ }^{75}$ Monsanto's lobbying efforts have been so successful that opponents argue that it holds undue influence over governments in preventing stringent regulations, with contacts in government generating the 'revolving door'. Although Monsanto's influence over government cannot be measured, indirectly it can be seen that GMO regulations in the United States have not changed drastically, and the principle of substantial equivalence for GM foods prevails.

In Mexico, companies may lobby the Mexican Congress, but they must be officially registered. In 2013, the LXII Chamber of Representatives had 252 registered lobbyists, including from Monsanto, Bayer and Cargill, represented by the Mexican Seeds Association. ${ }^{76}$ This shows lobbying as an important instrument to promote GM foods with the Mexican government, to build networks and as an instrument that opens the revolving door in the Mexican system.

Internationally, MNCs lobby for free trade and influence the discussion on investment protocols, encouraging particular sorts of technology. ${ }^{77}$ MNCs also lobby international organizations such as the Food and Agriculture Organization (FAO), which has been lobbied by the agrochemical industry. ${ }^{78}$ Moreover, industry lobbying groups are nowadays routinely present when environmental treaties are negotiated, because environmental issues have an economic impact on the industry, such as chemicals or biodiversity. ${ }^{79}$ During the party meetings of the Cartagena Protocol on Biosafety, ${ }^{80}$ industry groups have lobbied delegates in the corridors and hosted information sessions stressing the possible economic consequences of regulations that may be adopted

75 Bill Lambrecht, 'Monsanto Lobbies to Keep the Status Quo for Gene-Altered Crops', St. Louis Post-Dispatch (2005), available online at http://www.stltoday.com/stltoday/ news/stories.nsf/nation/story/11DD9EA02CA2A2258625707900 045E3 F=3FOpenDocume nt\&amp;highlight $=3 \mathrm{D} 2, \% 22$ Monsanto $=\% 22$.

76 Érika Ramírez, 'En las cámaras, 250 grupos de cabilderos al servicio de trasnacionales', Contralínea (Mexico City: 2013), available online at http://contralinea.info/archivorevista/index.php/2013/07/02/en-las-camaras-250-grupos-de-cabilderos-al-servicio-detrasnacionales/.

77 Rowlands, 'Transnational Corporations and Global Environmental Politics', p. 134.

78 Rowlands, 'Transnational Corporations and Global Environmental Politics', p. 139.

79 Jennifer Clapp, 'Transnational Corporate Interests in International Biosafety Negotiations', in Robert Falkner (ed.), The International Politics of Genetically Modified Food:Diplomacy, Trade and Law (New York, NY: Palgrave Macmillan, 2007), p. 3.

8o The Cartagena Protocol on Biosafety is an international agreement to ensure the safe handling, transport and use of GMOs. 
by the parties. ${ }^{81}$ Participation through industry groups has allowed companies to take a unified position that is not divided along regional or country lines, but is presented as an integrated position during the talks. ${ }^{82}$ Consequently, biotechnology companies have participated through industry groups and directly to have different ways of representation and form lobbying networks.

The implementation of lobbying networks as a long-term strategy has prevented a change in the regulatory status quo and allowed the revolving door to operate in favour of biotechnology firms. Although some authors consider lobbying as a single issue with short-term focus, ${ }^{83}$ this article argues that lobbying networks, particularly for biotechnology firms, are a relationship-building strategy, as observed in the GMo lobbying case.

\section{Conferences, Congresses and Seminars}

Conferences, congresses and seminars are valuable instruments to deliver corporate information, scientific findings and technical vocabulary, and to present recent developments to audiences interested in a specific topic. Seminars and public forums are a means to establish and sustain positive relationships with government representatives and stakeholders. ${ }^{84}$ These instruments offer the opportunity to exchange information about the latest biotechnology developments, talk about executive changes in the firms, or share ideas about new policies. ${ }^{85}$ They are essential instruments for networking, because attendees share converging interests.

Biotechnology companies do not directly organize these events, but support them through industry groups. For example, the Biotechnology Innovation Organization (в го) produces an annual event called the вго International Convention, bringing together biotechnology stakeholders from around the world, and meetings with investors and partners. ${ }^{86}$ This event hosts government representatives and non-government stakeholders. During the convention, biotechnology companies, pharmaceutical firms, industry groups, academic institutions, researchers from laboratories and government agencies

81 Robert Falkner, Business Power and Conflict in International Environmental Politics (New York, NY: Palgrave Macmillan, 2008), p. 175.

82 Clapp, 'Transnational Corporate Interests in International Biosafety Negotiations', p. 4.

83 Ruël and Wolters, 'Business Diplomacy', p. 568; Ruël, 'Diplomacy Means Business', p. 39; and Kesteleyn, Riordan and Ruël, 'Introduction: Business Diplomacy', p. 204.

84 Ruël and Wolters, 'Business Diplomacy', p. 571.

85 Peter Newell, 'Bio-Hegemony: The Political Economy of Agricultural Biotechnology in Argentina', Journal of Latin American Studies, vol. 41, no. 01 (2009) pp. 51-52.

86 Biotechnology Industry Organization (вго), 'About вıо', available online at https://www .bio.org/node/3089 (accessed 19 January 2015). 
come together to discuss trends or show new developments. This convention is important in economic and diplomatic terms because companies have a stall at the event and present corporate information and innovations. It is also a political event, because government agencies' representatives are present to have a voice at the convention and sometimes well-known politicians perform as keynote speakers.

At the BIO International Convention in 2014, former US Secretary of State Hillary Clinton was a keynote speaker. Her presence was relevant because biotechnology was a critical issue in her agenda and she was interested in gaining support from the biotechnology sector. Clinton had been in favour of GM foods and had promoted them as Secretary of State, representing American interests abroad:

I stand in favour of using seeds and products that have a proven track record. [...] We talk about drought-resistant seeds, and I've promoted them all over North Africa. By definition, they have been engineered to be drought-resistant; I mean that's the beauty of them.' ${ }^{87}$

Clinton recognized that the GM food debate had been unfolding for many years and tried to persuade politicians and policy-makers to change their perceptions about GM foods: 'I've been involved in a lot of political debates in other countries about whether or not to accept certain types of seeds' ${ }^{88}$ Hence, she has shaped the environment to make GM foods acceptable, a common goal of biotechnology companies. While in the Department of State, she started to switch the way in which food aid was undertaken by creating a programme called 'Feed the Future', which consisted of talking directly to farmers, not just working from the top with prime ministers or presidents, but from the bottom line with people involved in farming, eliminating their concerns and making people understand the topic better. ${ }^{89}$

The BIO conference may also influence the Mexican political environment. At the same convention, Mikel Arriola Peñalosa, director of the Federal Commission for the Protection against Sanitary Risk (COFEPRIs) at the time, participated as a speaker in three panels about opportunities for biotechnology. ${ }^{90}$ Arriola Peñalosa's participation was crucial, because

87 Hillary Rodham Clinton, 'Keynote', in вго International Convention (San Diego, CA: 25 June 2014), available online at https://mybio.org/profile/member/611436.

88 Clinton,'Keynote'.

89 Clinton, 'Keynote'.

90 BIO, 'Emerging Opportunities in Global Markets Forum Day 1', BIO International Convention, 2014, https://mybio.org/event/member/104558\#speakers. 
COFEPRIS is the agency that formulates sanitary regulations and decides which GM foods are authorized to be commercialized and consumed in Mexico. By attending this event, Arriola Peñalosa got up-to-date information about trends in biotechnology, and could receive privileged information by interacting directly with biotechnology companies' executives. He also reaffirmed his position in favour of biotechnology, which was transmitted to the rest of COFEPRIS personnel, because - as head - he sets the agenda at the commission.

\section{Awards}

These stimulating rewards may keep individuals interested in a specific topic, gain the attention of government agencies involved in regulations, and acknowledge individuals' careers and contributions. Biotechnology companies grant awards to government officials through industry groups; they do not award them directly to prevent the appearance of possible conflict of interest. However, officials who receive these awards may feel sympathetic to the industry. For example, during the vi CropLife International Forum in Mexico, CropLife's Latin America President Roberto Giesemann, who is also the DuPont Crop Protection Manager for Mexico and Central America, gave an award to Mikel Arriola Peñalosa. Giesemann recognized the work COFEPRIS has done in teamwork with the US Environmental Protection Agency and the Pro Modified Racing Association from Canada on a new analysis system for molecules, becoming a leading authority in Latin America and showing evidence of the scientific and technical level of its personnel. ${ }^{91}$ Arriola Peñalosa announced that new molecules would be for sale in the following months, and this system would allow Mexican farmers to access new technology and to reach US and Canadian levels. Consequently, biotechnology companies use awards as a business diplomacy instrument to extend their participation in society, reach policy-makers and influence them in some way, and foster relationships with government representatives and other stakeholders. Moreover, awards help to strengthen networks and relationships among companies and stakeholders.

\section{Research Centres}

MNCs rely on creating their own research centres to expand research and development, establish good relationships with the host government by giving prestige to the country and projection as a vanguard market regarding technology and innovation, provide new opportunities for employment as part of a growth

91 CropLife Latin America, 'VI Foro México 2013', Foro Internatinal CropLife, available online at http://www.croplifela.org/es/vi-foro-mexico-2013.html (accessed 4 March 2015). 
strategy, and implement innovative training and networks. Furthermore, establishing research centres in emerging markets is a way to build contentious business-society relations to change social attitudes towards MNCs, which are perceived or have acted as predatory actors, giving these firms the opportunity to become responsible partners of the society and community where they operate, and contributing to the sustainable development of the host country. ${ }^{92}$ Additionally, part of building a business diplomacy strategy to shape the political environment and attempt to minimize the impact of non-commercial risks in a host country consists of transferring diplomatic skills to the company's operation, including developing networks of information and influence, and building coalitions among key stakeholders. ${ }^{93}$ For example, biotechnology companies have established research centres in Jalisco, a Mexican state characterized by developing new technology clusters.

Monsanto launched its Global Centre of Technology to accelerate the development of hybrid maize seeds, and to support programmes for genetic improvement of maize from the United States and other parts of the world in 2014. ${ }^{94}$ Monsanto's Latin America General Director Manuel Bravo emphasized that this research centre affirms Monsanto's commitment to Mexico, because the centre would hire Mexican scientists and researchers and propose beneficial solutions for millions of farmers, including maize's tolerance to diseases and distress. ${ }^{95}$ Establishing this centre in Mexico gives Monsanto credibility, reputation and a sense of social responsibility, which are essential goals of business diplomacy.

Bayer CropScience opened a Seed Treatment Application Centre (STAC) in 2012, which was intended to advance the research of seeds and offer innovative technology to farmers. Mathias Haug, Bayer's Global Director of Seeds Treatment, explained that the centre's main purpose in Mexico is to provide advice and support to clients with state-of-the-art technology for the treatment of seeds and contribute to productivity and competitiveness. ${ }^{96}$ The STAC's activities are part of a long-term relationship-building strategy,

92 Saner and Yiu, 'Business Diplomacy Competence', pp. 313 and 314.

93 Riordan, 'Business Diplomacy', pp. 5 and 6.

94 'Monsanto instala centro global de tecnología para el desarrollo de híbridos de maíz en méxico', El Financiero (2014), available online at http://www.elfinanciero.com.mx/em presas/monsanto-instala-centro-global-de-tecnologia-para-el-desarrollo-de-hibridos-demaiz-en-mexico.html.

95 'Monsanto instala centro global de tecnología para el desarrollo de híbridos de maíz en méxico'.

96 Bayer CropScience México, 'Bayer CropScience inauguró su nuevo centro de alta tecnología para el tratamiento de semillas', Información de Prensa (2012), available at http:// bayer.com.mx/Bayer/CropScience/bcsmexico.nsf/id/STAC. 
including new products, technology and technical training. Moreover, this centre is part of a global network of ten centres, including in China, Brazil, Argentina and New Zealand, ${ }^{97}$ where Bayer is securing or gaining new markets and developing networks.

Syngenta opened its Seed Care Institute to develop protected and improved seeds, contribute to the genetic potential of seeds, and bring new seed technologies to increase farmers' productivity in Mexico and the rest of Latin America. ${ }^{98}$ Another part of this long-term business diplomacy strategy is to implement innovative public diplomacy strategies beyond marketing, ${ }^{99}$ such as the creation of public-private partnerships. For example, Syngenta has created a public-private partnership with the International Center for the Improvement of Maize and Wheat (СІммYт) and MasAgro ${ }^{100}$ to have more impact in the south-east of Mexico, where it expects to implement the use of hybrid varieties of high and new technology. ${ }^{101}$ This partnership represents big business for Syngenta because, in the future, it will sell its seeds to Mexican farmers or to the Secretariat of Agriculture (SAGARPA), which usually buys seeds to aid small-scale farmers. Additionally, SAGARPA is the government agency responsible for managing the MasAgro programme and allocates budget to this partnership.

Dow AgroSciences opened a research and development centre in 2013 focused on genetic solutions to improve agricultural products by introducing genes that alter food's features. ${ }^{102}$ Dow AgroScience's research centre is also involved in developing GM seeds to give solutions to farmers. This strategy allows Dow AgroScience to be closer to farmers, to project the research done at the centre, and to promote GM foods in a smoother way.

97 See online at http://news.agropages.com/News/NewsDetail---5957.htm, http://www.soya tech.com/print_news.php?id=27969; http://www.seedgrowth.bayer.co.nz/more/promot ing-a-fully-integrated-system-for-on-seed-applications-with-bayer-seedgrowth?id= \%7B65AD9o11-AE19-4F29-8678-5EC031905510\%7D.

98 Syngenta Colombia, 'Lanzamiento instituto seed care en mexico', Syngenta Noticias (2015), available online at https://www.syngenta.com.co/news/noticias/lanzamientoinstituto-seed-care-en-mexico.

99 Riordan, 'Business Diplomacy', p. 6.

100 A governmental program for agriculture.

101 María del Pilar Martínez, 'Biotecnología bajaría importación de granos: Syngenta', El Economista (2014), available online athttp://eleconomista.com.mx/industrias/2014/07/29/ biotecnologia-bajaria-importacion-granos-syngenta.

102 The Dow Chemical Company, 'Nuestra historia', Dow en México, available online at http:// www.dow.com/mexico/la/mex/es/about/history.htm (accessed 25 February 2015). 
DuPont Pioneer has opened research centres in four agricultural states in Mexico: Jalisco; Sinaloa; Guanajuato; and Chiapas. ${ }^{103}$ The south-east region's centre is intended to develop mainly hybrid maize seeds that are resistant to climate adversities in the region of Chiapas, Central America and the Caribbean, contributing to higher agricultural productivity. ${ }^{104}$ Ricardo García de Alba, DuPont Pioneer's Director for Latin America, expressed that this centre would contribute to increasing domestic corn production and food security. ${ }^{105}$ Having access to a market with over 100 million individuals becomes attractive for selling either hybrid or GM seeds, and these research centres form part of a network.

\section{Exhibits}

Exhibitions and expos are an opportunity for biotechnology companies to be in direct contact with producers, to show stakeholders the benefits of their technology and to build networks. This instrument of business diplomacy is helpful for a controversial issue such as GMOs, because it is a way to present biotechnology companies' points of view away from the opponents. Attendees at exhibits have the time and interest in the topic so they pay attention to what companies explain. For example, the Expo Agroalimentaria (Expo Agro-food) takes place annually in the state of Guanajuato, gathering international and domestic agrochemical and seed companies, government agencies and the general public. At the 2015 Expo Agroalimentaria, DuPont Pioneer presented a demonstrative parcel showing the benefits of its hybrid seeds, and DuPont Crops Protection presented a portfolio of pesticides. ${ }^{106}$ By showing an actual application of its products at the expo, farmers were made aware of these products' features and could be convinced of adopting DuPont's technology. DuPont Pioneer's Director Ricardo García de Alba highlighted the research centre, which has developed local high-development sorghum hybrids. ${ }^{107}$ This exhibit where the company's director is present, in addition to presenting

\footnotetext{
103 Oscar González-Escárcega, 'Ve DuPont escenario favorable en México', El Universal (2012), available online at http://www.eluniversal.com.mx/finanzas/93646.html.

104 Omar Becerril, 'DuPont se asienta en el sureste', Dinero en Imagen (2014), available online at http://www.dineroenimagen.com/2014-02-17/32758.

105 José de Jesús Zárate, 'Inauguran primer centro de investigación para el desarrollo agrícola del sureste mexicano', Agrosíntesis (Chiapa de Corzo, 2014), p. 13, available online at http://www.agrosintesis.com/component/content/article/49-front-page/922-inauguranprimer-centro-de-investigacion-para-el-desarrollo-agricola-del-sureste-mexicano.

106 Alejandra Gaucín, 'DuPont ofrece soluciones sustentables para el campo del Bajío mexicano', NN Noticias (2014), available online at http://www.alrojovivooaxaca.com/2014/11/ dupont-ofrece-soluciones-sustentables.html? $\mathrm{m}=0$.

107 Gaucín, 'DuPont ofrece soluciones sustentables para el campo del Bajío mexicano'.
} 
products and technical consulting, allows DuPont to refer to its research centres and gives opportunities for contact with the company director.

Other companies at the 2015 Expo Agroalimentaria were Monsanto, Dow AgroSciences, Syngenta and BASF, along with other independent seed companies from the United States such as United Genetics Seeds Co., and US Agriseeds Inc. Mexican government agencies such as SAGARPA and the National Service of Agro-Alimentary Health, Safety and Quality (SENASICA), as well as scientific institutions such as СІммYT, were also present. ${ }^{108}$ Business diplomacy recognizes that the ultimate goal is not to improve a company's reputation, but the core objective is to make profits for the firm. ${ }^{109}$ Therefore, this expo is a great venue to present products, disseminate information and research, and expose new advances in biotechnology. Expos where company directors appear are an opportunity for firms to exchange information with farmers and government representatives and are a manifestation of business diplomacy.

\section{Scientific Training}

Scientific training is a crucial instrument of public diplomacy for engaging with stakeholders, strengthening scientific cooperation and getting foreign companies to invest in the host country. ${ }^{110}$ MNCs also spend significant parts of their budgets to sponsor cultural, educational and scientific endeavours with the objective of buying goodwill. ${ }^{111}$ Scientific training in the long-term contributes to a closer relationship between the company and farmers, and is the perfect tool for educating producers about GM food advantages. This instrument has a sense of social responsibility because companies share knowledge with those who request it and are interested. Preparing and implementing scientific training involves incorporating specific ideas, vocabulary and methods to the training recipients. In order to increase the firm's influence in a positive or defensive way, business diplomacy consists of building multi-level networks of information and influence, as well as creating global and regional alliances with multiple stakeholders that share similar interests. ${ }^{112}$ The implementation of scientific training programmes with multiple stakeholders is thus an important relationship-building instrument of business diplomacy.

Monsanto's scientific training is implemented through academic collaboration, by sharing agronomic data and recommendations with academics

108 See http://registro.expoagrogto.ahmreg.com/directorio/giro.php\#academico to know all the participants.

109 Kesteleyn, Riordan and Ruël, 'Introduction: Business Diplomacy', p. 306.

110 Ordeix-Rigo and Duarte, 'From Public Diplomacy to Corporate Diplomacy', p. 552.

111 Haynal, 'Corporate Statecraft and its Diplomacy', p. 414.

112 Kesteleyn, Riordan and Ruël, 'Introduction: Business Diplomacy', p. 306. 
and universities to conduct GMO field trials with the objective of evaluating new products' safety and performance. ${ }^{113}$ Monsanto's scientists also serve as graduate-degree advisors and academic mentors because they maintain relations with the universities where they graduated and they participate in dissertation committees. ${ }^{114}$ Furthermore, Monsanto's strategy to change its image includes connection projects with society in 130 countries, with over 3,000 collaborators as ambassadors at schools in local communities promoting the use of technology in food. ${ }^{115}$ Working with academics and universities represents formal scientific training, whereas working in localities implies a friendlier way of training in the use of GM foods.

\section{Limitations and Further Research}

This article contributes to the discussion on what business diplomacy is and presents an analysis of strategies and instruments of business diplomacy that is scarce in the diplomatic literature. There is still discussion on the differences between public diplomacy, public relations, corporate social responsibility and business diplomacy. This article acknowledges that business diplomacy is a subset of public diplomacy, in which firms are the main actors implementing strategies and instruments to make the company advance its goals.

Analysis of the business diplomacy strategies and instruments proposed in this article has a contextual limitation. These have not been analysed at a supranational level by examining international organizations such as the World Trade Organization (WTO) or the FAO; these strategies are focused on the efforts implemented by biotechnology firms in the United States and Mexico. Moreover, the biotechnology companies analysed are limited to firms developing agricultural biotechnology, such as GMOs, fertilizers and pesticides, and not companies developing others sorts of biotechnology such as animals or drugs. Additionally, these strategies and instruments have been analysed in the context of the US-Mexico bilateral relationship, leaving other bilateral relations for further research. Finally, these business diplomacy strategies have

\footnotetext{
113 Monsanto, 'Collaborating with Academics and Universities', available online at http:// www.monsanto.com/improvingagriculture/pages/collaborating-with-academics-anduniversities.aspx (accessed 21 March 2016).

114 Monsanto, 'Collaborating with Academics and Universities'.

115 Roberto Arteaga, 'El mexicano que quiere cambiarle la cara a Monsanto', Forbes México (Des Moines: Forbes, 2014), available online at http://www.forbes.com.mx/el-mexicanoque-quiere-cambiarle-la-cara-monsanto/.
} 
not considered NGOs' activities, strategies and instruments to counterbalance forces in the GM food debate; that analysis is left for another article.

Further research could thus include analysing biotechnology companies' business diplomacy targeting international organizations, including the WTO and the FAO, to assess what strategies and instruments have been implemented to influence such regulatory bodies. Additionally, it would be worth studying what strategies and instruments biotechnology firms not focused on agriculture may employ to promote a stable political environment and gain a licence to operate' in other emerging countries beyond Mexico.

\section{Conclusions}

The business diplomacy strategies and instruments presented in this article have helped biotechnology companies to change perceptions of GM foods and gain some support from governments. One conclusion is that business diplomacy has helped to promote GM seeds among government agencies and has shaped the political environment in Mexico. Biotechnology companies have taken advantage of reactive strategies to respond not only to crises and evolving problems, but also to address controversial issues to project a favourable image of the company. For proactive strategies, the generation of audio-visual materials with CEOs, top executives and regional directors has been used as a signal of the company's interlocution with the rest of the world, and is a convenient instrument for emphasizing how these companies are socially responsible and may contribute to solving not only social problems of communities where they operate, but also to solving some of the world's problems such as relieving hunger, agricultural productivity and economic prosperity.

Another conclusion from this research is that a core function of business diplomacy is the creation and maintenance of long-term relationships. Relationship-building strategic communication has helped biotechnology firms to become more in contact with farmers because of the degree of specialization of some of the instruments used, and to interact with government officials who are also present at some of the events in which these companies participate. CEOs' and directors' participation at conferences, awards ceremonies and exhibits reflects the company's commitment to society and is a subtle way to disseminate information. This set of business diplomacy strategies and instruments has allowed biotechnology companies to advance their goals, secure markets and profitability, avoid stricter GMO regulations in Mexico, engage with different audiences at different levels, and give a sense of credibility and licence to operate in the host country. 
Yadira Ixchel Martínez Pantoja earned her Ph.D. in Politics and International Relations from the University of Auckland. Her research focuses on public diplomacy and the interactions of governments, multinational corporations and non-governmental organizations in regard to GM foods. Her areas of interest are public diplomacy, GMOs and food politics, state and non-state actors, and environmental politics. 